\title{
Q\&A: Peter Hessler on urbanization in China
}

\author{
In Country Driving, the final book in his China trilogy, Peter Hessler recounts his 11,000-kilometre drive across China to \\ see at first hand the effects of rapid industrialization. The New Yorker journalist explains how mass migration to cities \\ brings out people's resourcefulness, but also how the speed of social and environmental change leads them to seek \\ meaning in their lives.
}

\section{What did you hope to reveal about China in your trilogy? \\ Each book has a different focus: River Town (2001) looks at geography and place, Oracle Bones (2006) looks at history and time, and Country Driving looks at development and economics. I examine those issues through the experiences of the average Chinese person, in particular people who are making the transition from the countryside to the city. They are the driving force of China's industrial revolution. A main point is to look at how individuals, families and communities respond to those changes and new challenges.}

\section{How have improved roads and the automobile boom affected the nation's rural regions?}

Along my journey I was amazed by the pace of transition. I saw how quickly villages in northern China are emptying out because young people are migrating to cities for jobs, leaving young children behind to be raised by their grandparents. Many rural regions are far from urban centres so there are few opportunities for villagers to improve their livelihood. Roads and infrastructure allow them to get out - the young people hit the road for the east and the south. Building highways is normally the first step to urbanization. But in China, people can't buy and sell rural land. To develop it, local governments often move farmers off their land, turn it into urban land by building highways and infrastructures, and then sell it on at market rates.

\section{You followed the progress of a newly established factory town. What did you notice?}

I was struck by the adaptability of individuals. Spending time in a factory town, you realize just how quickly things are being built and how rapidly urbanization is taking place. One thing that impressed me was the functionality of the development system it is flawed, but the flaws are not fatal. It is very chaotic, the rules may be unfair, there is corruption, people tend to have a short-term view, but it works - for now at least. People know the rules and know how to advance to improve their situation. Those who move

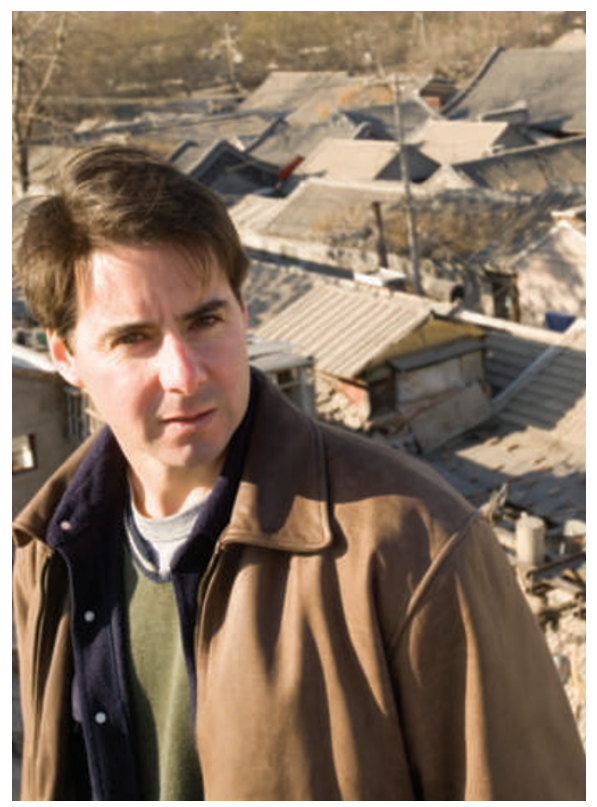

Peter Hessler: struck by Chinese adaptability.

into factory towns become resourceful and self-reliant. It is a tough world: when negotiating jobs, they have to learn how to manipulate people. There are positive aspects to this, such as increased individualism and capability, but the climate can be a bit brutal and lawless.

\section{How is China's industrial revolution different from those in Europe and the United States?}

One of the main differences is motivation. A shortage of labour in Europe and the United States inspired people to be innovative and efficient. China has so many workers that there is no need to save labour. This makes it a good place for low-margin production, but not so good for innovation or for making high-value-added products. China's political system, which lacks party competition, and its educational system, which is very controlled and traditional, also limit the possibility of innovation.

\section{Has the country's rapid development} affected people's sense of wellbeing? The pace of change can be overwhelming. There is a breakdown in values and sense of community. Families become more separated, geographically and emotionally. There is a sense of emptiness, a sense of something lacking. I met many 'searchers' in China, people who are concerned about what else there is in life beyond material success. They want a community and people they feel connected to. Many have developed a religious instinct - becoming followers of all sorts of faiths - but the religious institutions in China are poorly developed.

\section{How do people reconcile their sense of individual identity with the imposed collectivism?}

Individualism is becoming more characteristic in China. It arises outside the education system. The people who become migrants or entrepreneurs educate themselves, change their lives and adjust their outlook. And people have learned to take different roles in different circumstances: a farmer may act sometimes as a villager, as a city person, an entrepreneur or an obedient Party member. This is part of the general flexibility and adaptability of this generation: they are not stuck in a single framework.

\section{Does China's political system help or hinder its long-term economic development?}

In some ways it has been an asset in the past few decades. This is a society that has pulled more people out of poverty than any other in history; it has a high literacy rate, life expectancy has gone up, the per capita income has increased. It deserves credit for that. The question is how it gets to the next stage of development. It may reach a point when people become more resistant and demanding. When that happens, the system may either collapse or adapt to new challenges. But we haven't yet reached that point.

Interview by Jane Qiu, Nature's retained correspondent in Beijing.

e-mail: jane@janeqiu.com

Country Driving: A Journey Through China from Farm to Factory by Peter Hessler HarperCollins: 2010. 448 pp. \$27.99 